\title{
Pengembangan panduan konseling Islami berbasis model Gerald Corey
}

\author{
Ermalianti $\left.{ }^{1^{*}}\right)$ \\ Universitas Islam Negeri Antasari Banjarmasin ${ }^{1}$ \\ *) Alamat korespondensi: Jl. Jend. Ahmad Yani KM. 4.5, Banjarmasin, 70235, Indonesia; E-mail: ermalianti@fdk.uin- \\ antasari.ac.id
}

Article History:

Received: 06/02/2021;

Revised: 12/02/2021;

Accepted: $17 / 02 / 2021$

Published: 28/02/2021.

How to cite:

Ermalianti, E. (2021)

Pengembangan Panduan

Konseling Islami Berbasis Mode

Gerald Corey. Teraputik: Jurnal

Bimbingan dan Konseling, 4(3)

pp. 429-443. DOI:

10.26539/teraputik-43545
Abstrak: Penelitian ini dilatarbelakangi oleh ketiadaan panduan konseling Islami yang jelas dan sistematis. Tujuan penelitian adalah mengembangkan panduan konseling Islami berbasis Model Gerald Corey. Penelitian menggunakan penelitian dan pengembangan (R \& D) berdasarkan model Bord \& Gall dengan modifikasi oleh Sukmadinata. Tahap pengembangan meliputi: studi pendahuluan, pengembangan produk, validasi ahli dan pengguna. Teknik pengumpulan data terdiri dari kuisioner, observasi dan wawancara. Jenis data yang digunakan berupa data kuantitatif dan kualitatif. Hasil uji validasi Panduan konseling Islami berbasis Model Gerald Corey dari para ahli dan para calon pengguna menunjukkan nilai rata-rata empat (4) dengan kategori sangat tepat/sesuai. Dengan demikian, panduan koseling Islami berdasarkan model Gerald Corey telah memenuhi kriteria sangat tepat/sesuai dan layak untuk dipergunakan.

Kata Kunci: Pengembangan Panduan, Konseling Islami, Corey

Abstract: This research is motivated by the absence of clear and systematic Islamic counseling guidelines. The purpose of this research is to develop an Islamic counseling guide based on Gerald Corey's Model. This study uses a research and development (R \& D) approach based on the Bord \& Gall model modified by Sukmadinata. The development stage includes: preliminary studies, product development, expert and user validation. Data collection techniques consisted of questionnaires, observations and interviews. The type of data used is in the form of quantitative and qualitative data. The results of the validation test the Islamic counseling guide of Gerald Corey's model by experts and potential users shows an average value of four (4) with very precise / appropriate categories. Thus, the Islamic counseling guide based on Gerald Corey's model has met the criteria of being very appropriate and feasible to use.

Keywords: Module Development, Islamic Counseling, Corey access article distributed under the Creative Commons 4.0 Attribution License, which permits unrestricted use, distribution, and reproduction in any medium provided the original work is properly cited. (c) 2021 Ermalianti (s)

\section{Pendahuluan}

Bimbingan dan konseling, baik pada Perguruan Tinggi Negeri (PTN), maupun Perguruan Tinggi Swasta (PTS) yang mencetak tenaga ahli konselor tidak terlepas dari teori yang digunakan. Teori-teori konseling yang banyak dikembangkan dan dipakai para konselor di Indonesia umumnya diambil dari teori-teori Barat, seperti pendekatan Psikoanalitik, EksistensialHumanistik, Gestalt, dan lain sebagainya. Seperti yang sudah banyak dibuktikan dalam literatur ilmiah, konsep konseling dari Barat, khususnya konsep gabungan yang disampaikan oleh Gerald Corey, telah banyak memberi manfaat (Corey, 2017).

Pada konteks negara Indonesia dengan jumlah penduduk muslim yang besar di dunia, sentuhan nilai-nilai keagamaan dalam konteks konseling Islami perlu diberikan. Nilai-nilai keagamaan akan memberikan kecerdasan emosi (Sabiq, 2012), ketahanan diri terhadap stres (FERNANDY, no date), kemandirian (TYAS, no date), efikasi diri (Ristianti, 2018), kesehatan mental (INDRA, 2020; Ardani, Yusuf and Irawan, 2020; Vafaee, 2015; Martinez and Custodio, 2014; Ellison et al., 2013; Akbari and Hossaini, 2018; Pearce et al., 2019; Unterrainer, Lewis and Fink, 2014; Gonçalves et al., 2015), dan perubahan perilaku (Rudyanto, 2010; Siswanti, Muhsin and Nafisah, 2020) dengan kesadaran nilai-nilai yang dianut. Bahkan, spiritualitas ini juga 
mempengaruhi prestasi belajar (Ashshidieqy, 2018). Spiritualitas sebagai landasan nilai moral (Østbø, 2017; Stepanova, 2015; Brophy, 2015; Ushatikova et al., 2018; Hyland, 2017; Vitell et al., 2016; McGhee and Grant, 2017). Seseorang akan mengingat akhirat sebagai pertimbangan dalam berperilaku (Gudnanto, 2015).

Manfaat untuk konseli karena kebutuhan akan spiritual sangat dekat dengan individu yang secara fitrah mempunyai naluri beragama. Sebagaimana hasil penelitian Atmoko (2009) bahwa religiusitas yang kuat akan membuat lebih tenang, bertenaga, dan sejahtera cinta. Emosi tersebut terus terpelihara bahkan saat menghadapi stimulus buruk. Sebaliknya, religiusitas lemah membuat emosi tegang, kurang bertenaga, diliputi perasaan negatif. Emosi tersebut terbawa dalam kehidupan sehari-hari, sehingga respon emosinya negatif ketika menghadapi stimulus masalah.

Sayangnya, hingga kini literatur yang membahas tentang konseling Islami masih terbatas (Basri at. al., 2019). Padahal, konsep Islam itu sangat luas. Agama Islam sebenarnya ada istilah dakwah (Rozikan, 2017). Ketika seseorang memiliki masalah, ada solusi secara Islami, berdasarkan Qur'an \& Hadist (Fitri, 2018). Hanya saja, belum ada kajian yang khusus menggabungkan kelebihan bagaimana teori dari Barat, khususnya Gerald Corey, dengan konsep konseling Islami. Teori Barat memberikan sentuhan keefektifan secara ilmiah empirik, teori Islami memberikan sentuhan spiritualitas pada penyelesaian masalah konseli.

Teori-teori konseling Islami inilah yang digunakan di Jurusan BK Pendidikan Islam pada PT agama Islam. Hal ini tentu menjadi salah satu poin yang memerlukan perhatian. Konseling Islami memerlukan konsep tersendiri agar bisa berdiri sendiri dan memiliki ciri khas yang membedakanya dengan pendekatan lain. Oleh sebab itu, usaha pengembangan pendekatan konseling Islami merupakan suatu kebutuhan. Salah satunya dengan pengembangan konseling Islami berbasis Gerald Corey.

Konsep konseling Islami yang sistematis, runut, dan berpola selama ini belum ditemukan. Hal tersebut terbukti dari beberapa hasil penelitian. Berikut ini literatur penelitian konseling Islami. Sutoyo (2017) menjelaskan bahwa telah banyak model konseling yang dikembangkan untuk memecahkan permasalahan manusia. Namun, model tersebut hanya berbasis pada sains dan filsafat yang sifat kebenarannya bisa bertahan sementara (tentative). Dia menyebutkan bahwa model konseling berbasis nilai agama akan lebih tepat karena bersesuaian dengan psikologi yang menjadi landasan konseling selama ini. Dalam penelitiannya, Sutoyo (Sutoyo, 2017) mengembangkan model konseling sufistik yang bisa membantu anak menjadi pribadi yang shaleh.

Ma'ruf (2014) meneliti tentang rancangan konseling Islam aliran eksistensial-humanistik. Penelitiannya mendasari rumusan masalah untuk menyusun konsep konseling berwawasan Islam, yaitu: 1) bagaimana hakikat manusia menurut pandangan Islam, 2) bagaimana pandangan Islam tentang pribadi sehat, 3) bagaimana pandangan Islam tentang pribadi tidak sehat, dan 4) apa saja pokok-pokok ajaran Islam yang dapat digunakan untuk menangani masalah. Hasil penelitian lain, Tambunan (2018) menyebutkan bahwa perubahan tingkah laku menurut Quran tidak lain sebagai pendekatan konseling alternatif. Temuan pada penelitian ini dapat dijadikan input-proses dan produk konseling.

Hayat (2016) melakukan penelitian terkait konsep konseling berbasis ayat-ayat Al Qur'an terkait hakikat manusia dan kepribadian. Berdasarkan penelitian tersebut didapatkan hasil bahwa: 1) konsep Qur'an yang tidak dibahas dalam pendekatan konseling, yaitu manusia sebagai makhluk religius \& bagaimana kepribadian sehat, 2) sifat pembawaan dasar manusia. Konsep Freud bahwa manusia itu memiliki dasar berupa insting, yaitu sumber utama tenaga jiwa berupa tuntutan-tuntutan yang bersifat biologis. Menurut AI Qur'an, manusia memiliki pembawaan dasar berupa fitrah keimanan dan sumber kekuatan yang selalu menuntut teraktualisasinya nilai-nilai kebaikan dan kebenaran hakiki, 3) manusia adalah makhluk biologis, religius, pribadi, dan makhluk sosial.

Penelitian tersebut menunjukkan konseling Islami menjadi pembahasan yang penting dalam pendekatan konseling. Pentingnya spiritual dalam konseling menjadikan seorang konselor lebih manfaat. Konsep BK yang dikembangkan dengan pendekatan nilai agama bisa membantu konseli dalam memecahkan permasalah hidupnya dan mendapatkan ketentraman. Hal ini dikarenakan tujuan akhir dari BK Islam adalah konseli bisa mendapatkan keselamatan dan 
kebahagian di dunia dan di akhirat (Daulay, 2018). Oleh sebab itu, kajian tentang konsep BK Islam ini perlu mendapatkan perhatian lebih dengan menggunakan berbagai model dan perspektif.

Pada kajian lebih luas, penelitian pengembangan konseling Islami diuraikan sebagai berikut. (1) Penelitian pengembangan bimbingan kelompok berdasarkan konsep Islam dalam rangka meningkatkan kecerdasan sosial (Maulana, 2016). (2) Pengembangan BK berbasis pemikiran Al Ghazali untuk mengembangkan akhlak mulia (Gustini, 2016). (3) Pengembangan Bimbingan Konseling berbasis Al Qur'an (Hayat, 2017). (4) Pengembangan konseling berdasar Al Qur'an (Hayat, 2011). (5) Pengembangan BK Islami (Bastomi, 2017). (6) Pengembangan BK Islami untuk kesehatan (Arifin, 2013). (7) BK Islami untuk kecerdasan emosi (Fadhilah, 2017). (8) Pengembangan media BK Islami agar anak mandiri (Lestari, 2014). (8) Konseling Islami untuk parenting (Satriah, Tajiri and Yuliani, 2019). (9) Konseling Islami untuk pengembangan fitrah manusia (Siregar, 2015). (10) Pengembangan konseling Islami untuk kedisiplinan (Edison, 2018; Edison, 2020). (11) Pengembangan konseling berbasis pesantren (Arifin and Munfaridah, 2018). (12) Pengembangan konseling Islami di Malaysia (Zakaria and Akhir, 2017). (13) Pengembangan konseling Islami. (14) Konseling Islami untuk kesehatan mental (Lubis, 2011).

Berdasarkan literatur penelitian lain yang telah disebutkan tentang pengembangan konseling Islami, belum ada penelitian pengembangan konseling Islami berdasarkan model Gerald Corey. Jadi, sudah seharusnya pembahasan tentang topik ini juga terbuka lebar. Diperlukan penelitian pengembangan untuk melengkapi kekurangan dari penelitian-penelitian sebelumnya.

Menurut Sukmadinata (2012) penelitian pengembangan (RnD) adalah proses mengembangkan produk, baik baru, maupun menyempurnakan yang sudah ada dengan pertanggungjawaban. Trianto (2011) mengatakan bahwa $\mathrm{RnD}$ adalah metode penelitian ampuh untuk memperbaiki praktik. Adapun Darmadi (2011) mengemukakan bahwa RnD tujuan utamanya adalah bukan untuk merumuskan atau menguji teori tetapi mengembangkan hasil-hasil yang efektif untuk dimanfaatkan di sekolah-sekolah atau lembaga-lembaga lainnya.

Berdasarkan latar belakang di atas, pengembangan konseling Islami menjadi penting untuk menggagas inovasi tidak hanya menghasilkan produk pemecahan masalah, yang terjadi melainkan sekaligus untuk mengembangkan ilmu pengetahuan dalam bidang konseling Islami, yaitu pengembangan konseling Islami berbasis model Gerald Corey. Model ini dipilih karena buku Theory and Practice of Counseling and Psychotherapy yang ditulis oleh Corey (Corey, 2017), merupakan salah satu buku yang menjadi acuan para konselor.

Corey (Corey, 2017) menyajikan konsep filosofis konseling dengan sistematika dasar, meliputi: konsep kunci (pandangan tentang hakikat manusia, tentang kepribadian: pribadi sehat dan yang tidak sehat), proses terapeutik (sasaran konseling, fungsi dan peran konselor, pengalaman konseli dalam konseling, hubungan antara konseli, dan konselor), dan aplikasi (teknik dan prosedur konseling). Meskipun model ini telah popular di kalangan konselor, penelitian pengembangan dengan model ini masih terbatas, terutama terkait konseling berbasis nilai agama. Oleh sebab itu, penelitian ini penting untuk memperkaya kajian tentang model Gerald Corey dan implikasi praktis bagi konselor yang ingin menggunakan model ini di sekolah-sekolah berbasis agama Islam.

Rumusan masalah penelitian ini adalah bagaimana panduan konseling Islami berbasis model Gerald Corey? Tujuan penelitian dan pengembangan ini adalah untuk menghasilkan panduan konseling Islami berbasis model Gerald Corey yang teruji secara teoritis dan praktis. Manfaat penelitian ini terutama ditujukan pada pengembangan ilmu pengetahuan teoritis dan praktis bidang Bimbingan Konseling. Panduan konseling Islami ini diharapkan tepat dan berguna secara teoritik, serta tepat dan berguna secara praktik. Manfaat selanjutnya diharapkan dapat membantu guru BK atau dosen BK atau konselor, khususnya berbasis Islami, agar memiliki pedoman konseling Islami. 


\section{Metode}

Berkenaan dengan tujuan yang telah dipaparkan di latar belakang, penelitian ini digunakan metode Research \& Development. Penelitian ini meliputi analisis kebutuhan dan menguji produk supaya dapat dipergunakan di masyarakat. Pengembangan panduan konseling Islami ini merujuk pada rancangan Sukmadinata (2012) dan dimodifikasi dari sepuluh langkah Reseacrh \& Development (Borg, Gall, \& Gall ,2007).

Sepuluh langkah Reseacrh \& Development (Gall, Gall and Borg, 2007) tersebut dimodifikasi sesuai dengan kondisi dan kendala yang ada. Kemudian, dimodifikasi menjadi tiga tahap oleh Sukmadinata (2012). Tahap tersebut, yaitu: 1) studi pendahuluan; 2) pengembangan model; dan 3) uji model. Produk akhir yang diharapkan adalah berupa prototype panduan konseling Islami berbasis model Gerald Corey yang sudah diuji kelayakan, dan kebermanfaatannya sehingga bisa digunakan pasca penelitian.

Penelitian ini dilakukan di SMP Ar-Rahmah Putri (Boarding School) JI. Raya Jambu 01 Sumbersekar Day Malang sebagai tempat sekolah praktik uji pengguna program. Penelitian dilakukan sejak Februari 2019 mulai dari pengerjaan observasi, pengumpulan referensi, uji ahli dan revisi, uji pengguna dan revisi, hingga penyelesaian penelitian pada Februari 2021, kurang lebih dibutuhkan waktu dua tahun. Berikut ini Gambar 1. Prosedur penelitian.

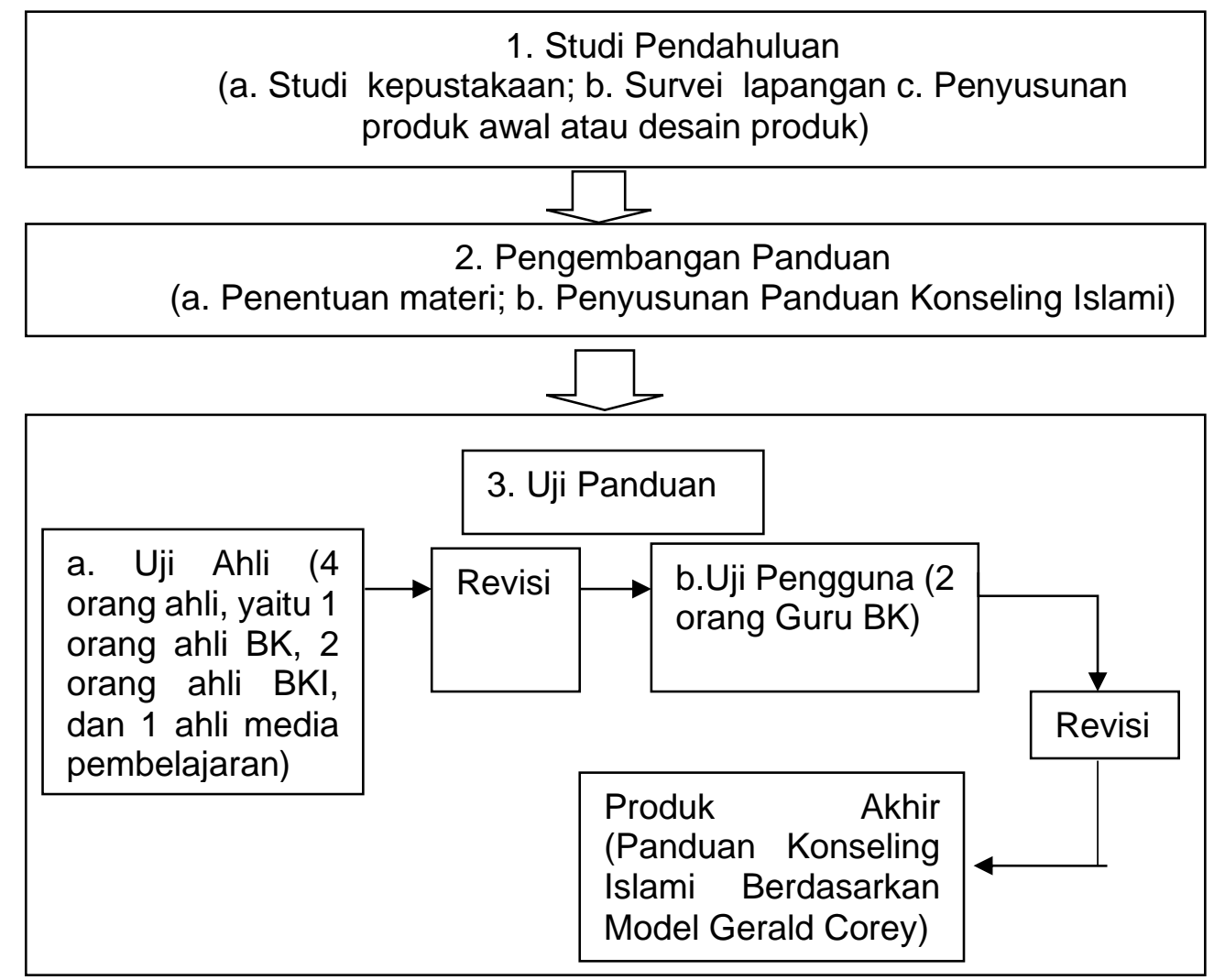

Gambar 1. Prosedur Pengembangan Panduan Konseling Islami Berbasis Model Gerald Corey Modifikasi Sumber: Dimodifikasi dari Sukmadinata (2012)

Teknik pengumpulan data terdiri dari kuisioner, observasi dan wawancara. Pengujian produk dilakukan pada uji ahli dan uji pengguna. Uji ahli dilakukan oleh empat orang ahli yang terdiri dari satu orang ahli bimbingan konseling (BK), dua orang ahli bimbingan konseling Islam (BKI), dan satu orang ahli media pembelajaran. Adapun uji pengguna dilakukan dengan melibatkan dua orang guru BK.

Peralatan yang digunakan untuk penelitian ini, antara lain: kertas HVS, alat tulis, map, dan penyimpan dokumen. Bahan penunjang yang digunakan adalah literatur, baik dari buku, dan internet, angket, pedoman observasi, dan wawancara. Ruang lingkup penelitian ini penelitian 
menggunakan desain penelitian dan pengembangan, penelitian dilakukan di satu sekolah, penelitian dilakukan selama dua tahun dari 2019-2020, dan penelitian berfokus pada konseling Islami menggunakan basic teori Gerald Corey. Keterbatasan metode penelitian R \& D berfokus "here and now", tidak mampu digeneralisasikan secara utuh karena pemodelannya pada sampel, bukan populasi.

\section{Hasil dan Diskusi}

Pemaparan subbab diskusi dan pembahasan dimulai dari hasil penyusunan awal produk. Kemudian, dipaparkan hasil penilaian penguji secara kuantitatif, disusul dengan pemaparan hasil penilaian penguji secara kualitatif, dan dilengkapi dengan pembahasan. Pertama, hasil penyusunan awal produk diuraikan sebagai berikut. Panduan konseling Islami berbasis model Gerald Corey berisi, antara lain: 1) hakikat manusia menurut Islam; 2) perkembangan perilaku dalam Islam yang meliputi struktur kepribadian dalam Islam, pribadi sehat dan yang tidak sehat dalam Islam; 3) hakikat konseling Islami; 4) kondisi pengubahan meliputi tujuan konseling Islami; 5) sikap, peran, tugas konselor Islam, dan tugas konseli, serta situasi hubungan konseling Islami; dan 6) mekanisme pengubahan mencakup tahap-tahap konseling Islami dan teknik-teknik konseling Islami. Setelah itu, dilakukan pengujian untuk bisa lebih baik.

Ketepatan dan kesesuaian panduan konseling Islami berbasis model Gerald Corey dilakukan validitas dan diperjelas dengan melakukan diskusi kepada para penguji. Para penguji dalam pengembangan panduan konseling Islami model Gerald Corey, meliputi penguji ahli dan penguji pengguna. Uji ahli terdiri dari ahli Bimbingan Konseling (BK), ahli Bimbingan Konseling Islami (BKI), dan ahli media pembelajaran.

Adapun data kuantitatif atau data hasil penilaian umum mengenai panduan konseling Islami berbasis model Gerald Corey diperoleh berdasarkan uji ahli dan uji pengguna. Berikut ini adalah pemaparan data kuantitatif hasil penilaian dari (1) uji ahli BK, (2) uji ahli BKI, (3) uji ahli media pembelajaran, dan (4) uji pengguna.

Uji ahli dari bimbingan dan konseling diwakili oleh Prof. Dr. Nur Hidayah, M.Pd. Uji ahli dari Bimbingan Konseling Islam oleh Dra. Hj. Romdiyah, M.Pd dan Dr. Hidayat Ma'aruf, M.Pd. Indikator dari data penilaian umum panduan konseling Islami berbasis model Gerald Corey oleh penguji terdiri dua aspek yaitu: 1) kesesuaian materi dan 2) kepraktisan pelaksanaan. Penilaian kuantitatif dari uji ahli BK dan BKI dalam aspek ketepatan dan kesesuaian panduan konseling Islami berbasis model Gerald Corey terdiri dari 12 item dengan gradasi 1 - 4. Adapun skor minimal $1 \times 12=12$, sedangkan skor maksimal adalah $4 \times 12=48$. Dengan membandingkan skor minimal dan skor maksimal diperoleh selisih 36. Lalu, menentukan interval untuk membuat kriteria dengan membagikan beda skor dengan $4(36: 4=9)$. Berikutnya, diperoleh kriteria dalam Tabel 1. Kriteria Skor Penilaian Uji Ahli BK dan BKI sebagai berikut.

Tabel 1. Kriteria Skor Penilaian Uji Ahli BK dan BKI

\begin{tabular}{cc}
\hline Skor & Klasifikasi \\
\hline $39-48$ & Sangat tepat/sesuai \\
\hline $29-38$ & Tepat/sesuai \\
\hline $20-28$ & Kurang tepat/sesuai \\
\hline$<20$ & Tidak tepat/sesuai
\end{tabular}

Sumber: Diolah dari data penelitian UM (2020)

Penilaian dari uji ahli BK memberikan skor empat 4 pada semua item pertanyaan, sehingga total skor adalah 48. Produk mendapat rata-rata hasil validasi adalah 4 dengan kategori sangat tepat/sesuai. Berdasarkan kriteria skor penilaian uji ahli BK pada Tabel 1 di atas, produk masuk dengan skor 48 masuk kategori sangat tepat/sesuai.

Pada penilaian secara kuantitatif dari uji ahli BKI, skor kuisioner oleh uji ahli pertama adalah 42 dan oleh uji ahli kedua 40. Rata-rata hasil dari kuisioner panduan konseling Islami oleh 
ahli BKI, ahli pertama menilai 3,5 dan oleh ahli kedua 3,3. Dengan demikian, panduan konseling Islami berbasis model Gerald Corey memenuhi kriteria tepat/sesuai/praktis.

Penilaian uji ahli media pembelajaran diwakili oleh Eka Pramono Adi, S.Ip., M.Si. Indikator dari data kuantitatif penilaian umum panduan konseling Islami berbasis model Gerald Corey oleh uji ahli media pembelajaran terdiri dari lima indikator yaitu: 1) kesesuaian, 2) ketepatan, 3) kejelasan, 4) kemudahan, dan 5) kemenarikan. Panduan konseling Islami berdasarkan model Gerald Corey terdiri dari 13 item dengan gradasi skor $1-4$. Adapun skor minimal $1 \times 13=13$, sedangkan skor maksimal adalah $4 \times 13=52$. Skor minimal dibandingkan dengan skor maksimal dan diperoleh selisih 40. Lalu, menentukan interval untuk membuat kriteria dengan membagikan beda skor dengan $4(40: 4=10)$. Berdasarkan interval skor 4 , diperoleh kriteria yang dijelaskan dalam Tabel 2. Kriteria Skor Penilaian Uji Ahli Media Pembelajaran di bawah ini.

Tabel 2. Kriteria Skor Penilaian Uji Ahli Media Pembelajaran

\begin{tabular}{cc}
\hline Skor & Klasifikasi \\
\hline $43-52$ & Sangat sesuai/tepat/jelas/mudah/menarik \\
\hline $33-42$ & Sesuai/tepat/jelas/mudah/menarik \\
\hline $23-32$ & $\begin{array}{c}\text { Kurang sesuai/kurang tepat/kurang jelas/kurang } \\
\text { mudah/kurang menarik }\end{array}$ \\
\hline$<23$ & Tidak sesuai/tidak tepat/tidak jelas/tidak mudah/tidak \\
menarik
\end{tabular}

Sumber: Diolah dari data penelitian UM (2020)

Tabel 2 menunjukkan bahwa setiap klasifikasi terdiri dari 10 skor. Kriteria skor penilaian uji ahli media pembelajaran akan dinilai sangat sesuai/tepat/jelas/mudah/menarik ketika dalam interval 43-52. Setiap 10 skor ke bawahnya, misalnya, 33-42 masuk dalam klasifikasi sesuai, dan seterusnya.

Penilaian dari uji ahli media pembelajaran memberikan total skor 47. Nilai rata-rata hasil validasi produk 3,6 dengan kategori sesuai/tepat/jelas/mudah/menarik. Berdasarkan kriteria skor penilaian ahli media pembelajaran pada tabel 2 di atas, produk masuk dengan skor telah memenuhi kriteria sesuai/tepat/jelas/mudah/menarik dari ahli media pembelajaran.

Terakhir, penilaian secara kuantitatif dari uji ahli pengguna dilakukan oleh Vonny Fatimah, S.Pd dan Indah Rahma Lathifiathin, S.Pd.I. Data hasil penilaian ahli pengguna dengan indikator dari data penilaian umum panduan konseling Islami berdasarkan model Gerald Corey terdiri dari tiga indikator, yaitu: 1) kemudahan, 2) kegunaan, dan 3) kemenarikan. Skor validasi setelah revisi panduan konseling Islami berbasis model Gerald Corey oleh uji ahli pengguna pertama adalah 40 dan uji ahli pengguna kedua adalah 33. Rata-rata hasil validasi oleh uji ahli pengguna pertama adalah 4 dan uji ahli pengguna kedua adalah 3,3 dengan kategori sesuai/tepat/jelas/mudah/menarik. Berdasarkan kriteria skor penilaian uji ahli pengguna, produk telah memenuhi kriteria sesuai/tepat/jelas/mudah/menarik.

Kriteria-kriteria sesuai/tepat/jelas/mudah/menarik di atas dipertegas dengan wawancara kepada uji ahli media pembelajaran. Berikutnya, dipaparkan pembahasan data penilaian kualitatif. Data penilaian kualitatif ini diperoleh dari para penguji dengan melakukan analisis dari saran, komentar, dan kritik. Data kualitatif tersebut dipaparkan apa adanya sebagai bahan pertimbangan untuk revisi dan penyempurnaan panduan konseling Islami berbasis model Gerald Corey.

Berdasarkan uji ahli BK panduan konseling Islami berbasis model Gerald Corey, dinilai sangat tepat/sesuai karena secara sistematis telah memuat: 1) hakikat manusia menurut Islam, 2) perkembangan perilaku dalam Islam meliputi struktur kepribadian Islam dan pribadi sehat dan yang tidak sehat dalam Islam, 3) hakikat konseling Islami, 4) kondisi pengubahan meliputi tujuan konseling Islami, sikap dan tugas konselor Islam, dan sikap, peran dan tugas konseli, serta situasi hubungan konseling Islami, 5) mekanisme pengubahan mencakup tahap-tahap konseling Islami dan teknik-teknik konseling Islami yang telah sistematis dalam konseling. Panduan konseling Islami berbasis model Gerald Corey tersebut dinilai telah memenuhi kriteria sangat tepat/sesuai karena secara sistematis telah memenuhi model Gerald Corey. 
Uji ahli BK juga menilai secara rinci panduan konseling Islami berbasis model Gerald Corey. Uraian tersebut sebagai berikut.

1. Hakikat manusia pada panduan dinilai sangat tepat, sebagaimana pendekatan konseling yang lainnya, pembahasan pendekatan konseling diawali dengan hakikat manusia. Hakikat manusia merupakan pembahasan pokok yang merupakan konsep kunci sehingga bisa dilanjutkan dengan konsep-konsep yang lain. Sebagaimana yang dinyatakan Solihin \& Rosihon (2004) bahwa manusia dalam perspektif spiritual Islam adalah makhluk yang secara fitrahnya dipengaruhi oleh kecenderungan-kecenderungan jiwanya. Berdasarkan hal tersebut maka akan terurai perkembangan perilaku, hakikat konseling Islami, kondisi pengubahan dan mekanisme pengubahan.

2. Hakikat konseling Islami pada panduan konseling Islami berbasis model Gerald Corey dinilai sangat tepat/sesuai karena pendekatan konseling lainnya memuat hakikat konseling. Hakikat konseling Islami memiliki kekhasan karena berlandaskan kepada pedoman umat Islam yaitu Qur'an \& hadits. Kekhasannya tersebut terletak pada hakikat konseling Islami yang berbeda dari teori dan pendekatan konseling yang lainnya. Sebagaimana penelitian oleh Diniaty (2013) tentang urgensi teori konseling dan perspektifnya dalam Islam menjawab tuntutan konseling religius di masa depan menyatakan bahwa Islam sebagai agama memandang konseling sebagai kegiatan ibadah dan banyak dibahas dalam Qur'an $\&$ hadits tentang pelaksanaan kegiatan konseling.

3. Perkembangan perilaku dalam Islam pada panduan konseling Islami berbasis model Gerald Corey dinilai sangat tepat/sesuai karena pada pendekatan konseling lainnya memuat perkembangan perilaku yang mencakup struktur kepribadian dan pembahasan pribadi sehat dan tidak sehat. Perkembangan perilaku dalam Islam yang mencakup karakter Islam sudah memaparkan bagaimana gambaran kepribadian Islam dengan batasan model Gerald Corey. Panduan yang dibuat telah menguraikan dengan jelas karakteristik pribadi sehat dalam Islam dan yang tidak sehat dalam Islam. Uraian ini sangat diperlukan karena fungsi BK Islam adalah membantu individu agar menyadari eksistensinya, yaitu sebagai makhluk Allah. Konselor diharapkan bisa mengarahkan konseli untuk mengenali dan menerapkan pribadi sehat menurut Islam (Ardi, 2019).

4. Kondisi pengubahan, meliputi tujuan konseling Islami, sikap dan tugas konselor Islam, dan sikap, peran dan tugas konseli, serta situasi hubungan konseling Islami dinilai sangat tepat/sesuai karena pendekatan konseling lainnya memuat hal tersebut. Pemaparan tujuan konseling Islami telah tergambar jelas baik tujuan umum maupun tujuan khusus dengan membentuk insan kamil (sempurna). Sikap, peran dan tugas konselor tepat/sesuai dengan memberikan kriteria konselor Islam. Sikap, peran dan tugas konseli yang telah dipaparkan pada panduan konseling Islami berbasis model Gerald Corey adalah konseli yang bersedia konseling dengan pendekatan Islam. Adapun situasi hubungan konseling Islami telah memenuhi kriteria pendekatan konseling, dengan adanya hubungan kerjasama, konseli aktif dan pertimbangan nilai-nilai Islam.

5. Mekanisme pengubahan mencakup tahap-tahap konseling Islami dan teknik-teknik konseling Islami telah memenuhi kriteria sangat tepat/sesuai. Tahap-tahap konseling memberikan gambaran tahapan konseling Islam dan teknik konseling Islami memenuhi teknik konseling. Teknik dalam konseling Islami tersebut sangatlah beragam, pendekatan spiritual sangatlah dekat dengan ketenangan konseli.

Berdasarkan uji ahli BKI panduan konseling Islami berbasis model Gerald Corey, dinilai tepat/sesuai karena secara sistematis telah memuat: 1) hakikat manusia menurut Islam, 2) perkembangan perilaku dalam Islam meliputi struktur kepribadian Islam dan pribadi sehat dan yang tidak sehat dalam Islam, 3) hakikat konseling Islami, 4) kondisi pengubahan meliputi tujuan konseling Islami, sikap dan tugas konselor Islam, dan sikap, peran dan tugas konseli, serta situasi hubungan konseling Islami, 5) mekanisme pengubahan mencakup tahap-tahap konseling Islami dan teknik-teknik konseling Islami yang telah sistematis dalam konseling dan memenuhi kriteria tepat/sesuai karena sesuai dengan konsep konseling Islami. 
Uji ahli BKI juga menilai secara rinci panduan konseling Islami berbasis model Gerald Corey. Uraian tersebut sebagai berikut.

1. Hakikat manusia dalam Islam yang terdapat pada panduan konseling Islami berbasis model Gerald Corey dinilai tepat/sesuai dengan konsep hakikat manusia dalam Islam. Hakikat manusia selalu menjadi perbincangan yang hangat, dalam konseling Islami konsep hakikat manusia dalam Islam bersumber dari Qur'an \& hadits yang menjadi pijakan pokok. Hakikat manusia dalam Islam tersebut merupakan kata kunci bagi sub konsep konseling Islami yang lain. Sebagaimana hasil penelitian Hayat (Hayat, 2016) tentang konsep konseling berbasis Al Qur'an tentang hakikat manusia, pribadi sehat dan yang tidak sehat bahwa secara umum konsep tersebut relevan dengan konsep konseling.

2. Perkembangan perilaku dalam Islam yang mencakup struktur kepribadian Islam, pribadi sehat dan yang tidak sehat pada panduan konseling Islami berbasis model Gerald Corey memenuhi kriteria tepat/sesuai. Struktur kepribadian Islam dinilai sangat tepat/sesuai karena telah memenuhi konsep kepribadian Islam yang terdapat dua hal yang akhirnya bisa dikatakan kepribadian Islam, yaitu pola pikir Islam dan pola sikap Islam. Pribadi sehat dan yang tidak sehat dalam Islam pada panduan konseling Islami berbasis model Gerald Corey dinilai tepat/sesuai dilihat dari terintegrasinya individu dengan aqidah Islam, terikat dengan aturan Allah SWT atau sebaliknya.

3. Hakikat konseling Islami pada panduan konseling Islami berbasis model Gerald Corey dinilai sangat tepat/sesuai karena telah memuat konsep hakikat konseling Islami. Hakikat konseling Islami berlandaskan kepada pedoman umat Islam yaitu Qur'an \& hadits. Landasan hakikat konseling Islami dengan pedoman Qur'an \& hadits menjadi pijakan mendasar bagi pelaksanaan konseling tersebut. Sebagaimana pernyataan Hallen (2005) bahwa Qur'an \& hadits yang berisikan pedoman tentang sikap dan perilaku yang diridhai Allah SWT dan yang tidak, akan mempengaruhi perkembangan fitrah beragama manusia.

4. Kondisi pengubahan meliputi tujuan konseling Islami, sikap dan tugas konselor Islam, dan sikap, peran dan tugas konseli, serta situasi hubungan konseling Islami dinilai tepat/sesuai karena menggunakan konsep Islam. Pemaparan tujuan konseling Islami telah tergambar jelas baik tujuan umum maupun tujuan khusus dengan membentuk insan kamil (sempurna) yang terintegrasi dengan aqidah Islam. Sikap, peran dan tugas konselor Islam tepat/sesuai dengan kriteria konselor Islam yang menguasai konseling Islam dari teori dan praktek. Sikap, peran dan tugas konseli yang telah dipaparkan pada panduan konseling Islami melalui model Gerald Corey adalah konseli yang bersedia konseling dengan pendekatan Islam. Adapun situasi hubungan konseling Islami telah memenuhi kriteria konsep Islam, dengan adanya hubungan kerjasama, konseli aktif dan pertimbangan nilai-nilai Islam, termasuk mempertimbangkan konseli yang berlawanan jenis.

5. Mekanisme pengubahan mencakup tahap-tahap konseling Islami dan teknik-teknik konseling Islami telah memenuhi kriteria sangat tepat/sesuai. Tahap-tahap konseling memberikan gambaran tahapan konseling Islam dan teknik konseling Islami memenuhi konsep Islam. Teknik dalam konseling Islami tersebut sesuai/tepat dengan konsep dalam Islam. Agama Islam membolehkan metode dan teknik apapun yang digunakan dalam memecahkan permasalahan selama tidak bertentangan dengan nilai-nilai dan ajaran Islam.

6. Kelebihan panduan konseling Islami berbasis model Gerald Corey adalah dalam kepraktisan mempraktikan konseling Islami. Panduan ini dilengkapi dengan video gambaran konseling Islami. Revisi pada panduan tersebut dengan adanya catatan, masukan, dan saran berupa: a) sebaiknya konsep dasar model Gerald Corey dijelaskan terlebih dahulu baru konsep dasar konseling Islami, b) konsistensi penggunaan istilah konseling Islami/Islam, c) perbaiki penulisan, d) kemukakan ayat-ayat AI Qur'an yang digunakan tidak hanya sekedar artinya, e) pada poin hakikat konseling, sikap dan tugas konseli, Islam sebaiknya menggunakan landasan ayat Al Qur'an atau hadits, f) munculkan pada verbatim kekhasan konseling Islami seperti halnya anjuran untuk berwudhu, sholat istiharah atau yang lainnya. g) agar peneliti berhatihati dalam mengambil konsep terutama pada pembahasan hakikat manusia terkait ruh karena masih dalam pembahasan. 
Berdasarkan uji ahli media pembelajaran bahwa kelebihan panduan konseling Islami berbasis model Gerald Corey secara deskriptif verbal maupun secara kuantitatif memenuhi kriteria sesuai/tepat/jelas/mudah/menarik. Kelebihan panduan konseling Islami tersebut dari segi: 1) jenis huruf yang digunakan, 2) pemilihan ukuran teks, 3) pemilihan warna, 4) pemilihan komparasi warna, 5) penggunaan desain/rancangan penyajian, 6) pemilihan background, 7) ukuran gambar, 8) sajian gambar, 9) informasi pada ilustrasi gambar, 10) penggunaan bahasa, 11) kemudahan dibaca, 12) tampilan fisik, dan 13) layout telah memenuhi kriteria sesuai/tepat/jelas/mudah/menarik. Kelebihan produk panduan konseling Islami berbasis model Gerald Corey pada komparasi warna sangatlah sesuai. Hal tersebut sangatlah penting dari penampilan sebuah produk pengembangan. Termasuk penggunaan foto pada produk pengembangan. Uji ahli memberi saran agar foto pada panduan menarik dengan menggunakan foto normal (berwarna seperti aslinya). Penggunaan foto lebih banyak untuk keperluan penelitian yang menghasilkan data deskriptif. Sebagaimana pernyataan Moleong (2011) bahwa foto menghasilkan deskriptif yang berharga untuk menelaah segi subjektif dan dianalisis secara induktif.

Berdasarkan uji pengguna kelebihan panduan konseling Islami berbasis model Gerald Corey, yaitu adanya gambaran: 1) hakikat manusia dalam Islam, 2) perkembangan perilaku dalam Islam, 3) hakikat konseling Islami, 4) kondisi pengubahan, 5) mekanisme pengubahan, 6) proses pelaksanaan konseling Islam/praktis, 7) manfaat panduan konseling Islami bagi konseli, 8) manfaat panduan konseling Islami bagi konselor, 9) desain cover, dan 10) kemenarikan layout, yang dinilai mudah/berguna/menarik.

Uji pengguna juga menilai secara rinci panduan konseling Islami berbasis model Gerald Corey. Uraian tersebut sebagai berikut.

1. Hakikat manusia dalam Islam mudah dipahami karena penjelasan yang sesuai fitrah manusia, bisa diterima akal, dan menentramkan hati. Konsep manusia dalam Islam berlandaskan kepada Qur'an \& hadits yang secara keseluruhan bahwa manusia terdiri dari jasad dan ruh. Manusia memiliki akal dan potensi/naluri, serta kebutuhan jasmani. Sejalan dengan manusia lemah dan membutuhkan yang lainnya.

2. Perkembangan perilaku dalam Islam yang mencakup struktur karakter, pribadi sehat, dan yang tidak sehat pada panduan konseling Islami berbasis model Gerald Corey memenuhi kriteria mudah dipahami. Kelebihan panduan tersebut pada struktur karakter memberikan kriteria karakter Islam yang seharusnya sejalan antara pola pikir Islam dengan pola sikap Islam. Pribadi sehat adalah pribadi yang terintegrasi dengan aqidah Islam. Pribadi sehat kehidupannya akan sesuai dengan aturan. Sebaliknya, pribadi tidak sehat tidak menjadikan aqidah Islam sebagai standar. Pada konsep Islam, manusia dilahirkan secara fitrah yang berarti lahir dengan membawa nilai-nilai original dan sifat-sifat asli. Sifat-sifat ini kemudian mendapat pengaruh eksternal yang mengubah perilakunya (Gustini, 2016). Perilaku keseharian yang disebabkan oleh daya pengaruh dari dalam diri insan dan luar diri insan ketika berinteraksi dengan dirinya sendiri, Allah SWT, kedua orang tuanya, suami-istri, ayahanak, kerabat, tetangga, teman dan pergaulan sosial butuh aturan.

3. Hakikat konseling Islami pada panduan konseling Islami berbasis model Gerald Corey dinilai mudah dipahami karena telah memuat konsep hakikat konseling Islami yang jelas berlandaskan Qur'an \& hadits. Konseling Islami merupakan proses penyelesaian masalah berlandaskan nilai-nilai Islam sangat membantu dalam dunia pendidikan. Sebagaimana hasil penelitian Indrayati (2020) bahwa layanan bimbingan konseling Islam yang dilaksanakan di sekolah dapat dicapai dengan baik karena komponen yang ada di sekolah diarahkan untuk membentuk kepribadian muslim bagi anak didiknya, serta kreativitas dan profesionalisme konselor dalam menyampaikan bimbingan sehingga mampu menumbuhkan minat peserta didik untuk memahami, menghayati dan mengamalkan nilai-nilai Islam dalam kehidupan sehari-hari.

4. Kondisi pengubahan meliputi tujuan konseling Islami; sikap dan tugas konselor Islam, serta sikap dan tugas konseli; dan situasi hubungan konseling Islami dinilai sangat mudah dipahami. Hal ini dikarenakan, pemaparan tujuan konseling Islami telah tergambar jelas baik tujuan umum maupun tujuan khusus dengan membentuk insan kamil (sempurna) yang terintegrasi dengan aqidah Islam. Sikap, peran dan tugas konselor Islam mudah dipahami 
dengan kriteria konselor Islam yang menguasai konseling Islam dari teori dan praktik. Sikap dan tugas konseli yang telah dipaparkan pada panduan konseling Islami berbasis model Gerald Corey adalah konseli yang bersedia konseling dengan pendekatan Islam mudah untuk dipahami. Adapun situasi hubungan konseling Islami telah mudah dipahami dengan adanya suri tauladan, hubungan kerjasama, konseli aktif dan pertimbangan nilai-nilai Islam, termasuk mempertimbangkan konseli yang berlawanan jenis.

5. Mekanisme pengubahan mencakup tahap-tahap konseling Islami dan teknik-teknik konseling Islami sangat mudah dipahami. Tahap-tahap konseling memberikan gambaran alur tahapan konseling Islam. Teknik konseling Islami mudah dipahami dengan uraian per teknik. Teknik dalam konseling Islami tersebut mudah dipahami karena dilengkapi dengan video konseling. Teknik konseling Islami mudah dipraktikkan karena secara aktivitas sudah sering dilakukan, labih lagi ada dorongan untuk melaksanakannya karena bernilai ibadah.

6. Panduan konseling Islami berbasis model Gerald Corey bermanfaat untuk konseli dan konselor. Emosi akan menjadi lebih baik ketika religiusitas berkualitas. Konseling Islami diharapkan mempengaruhi religiusitas konseli dan konselor karena mengingatkan kembali nilai-nilai religiusitas.

Panduan konseling Islami berbasis model Gerald Corey menurut ahli bimbingan konseling adalah sangat tepat/sesuai dan praktis, menurut dua ahli bimbingan konseling Islam adalah tepat/sesuai dan praktis, dan menurut ahli media pembelajaran adalah sesuai/tepat/jelas/mudah/menarik. Panduan konseling Islami berbasis model Gerald Corey menurut dua calon pengguna atau konselor; calon pengguna pertama menilai sangat mudah/berguna/menarik, dan calon pengguna kedua mudah/berguna/menarik. Hal ini berarti panduan konseling Islami berbasis model Gerald Corey memenuhi kriteria sangat tepat/sesuai dan kepraktisan pelaksanaan, hanya saja masih ada yang diperlukan revisi seperti pada penjelasan kualitatif di atas.

Penyempurnaan pada panduan konseling Islami berbasis model Gerald Corey dilakukan dengan adanya masukan dan saran berupa: 1) penggunaan judul yang rancu, 2) desain cover, 3) penggunaan SK Menteri Pendidikan dan Kebudayaan Republik Indonesia yang terbaru, 4) memperjelas sikap dan tugas konseli, 5) situasi hubungan ditambah penjelasan, 6) teknik konseling, 7) memperbaiki kesalahan penulisan, 8) verbatim ditambah keterangan, dan 9) daftar pustaka perlu disesuaikan dengan isi produk.

Sebagaimana pengembangan konseling Islami yang dikembangkan oleh Ma'ruf (Ma'ruf, 2014) yang menyatakan belief system (nilai-nilai keyakinan) harus dipertimbangkan agar intervensi terapi berlangsung efektif. Hal tersebut akan terwujud ketika pemberian proses konseling dengan mempertimbangkan keyakinan, pandangan, dan sikap konseli terhadap agamanya. Keyakinan terhadap agama mempengaruhi seluruh kehidupan seseorang. Panduan konseling Islami berbasis model Gerald Corey tersebut bisa menjadi rujukan bagi konselor Islam yang konselinya bersedia dengan pendekatan tersebut.

Foto yang digunakan pada panduan konseling berdasarkan model Gerald Corey adalah foto yang dihasilkan sendiri. Dalam penelitian kualitatif yang dinyatakan oleh Bogdan dan Biklen (2003), baik foto yang dihasilkan orang lain, maupun sendiri dapat dimanfaatkan. Penggunaan foto untuk melengkapi data jelas besar sekali manfaatnya.

Kelengkapan lainnya yang terdapat dalam panduan konseling berdasarkan model Gerald Corey adalah dengan dicantumkannya pula sasaran pengguna panduan. Pengguna panduan konseling Islami adalah konselor Islam. Konselor Islam, sebagaimana pernyataan Amin (2010) dalam tugasnya membantu konseli harus memperhatikan nilai-nilai Islami. Oleh karena itu, konselor Islami profesional seharusnya memiliki pengetahuan bimbingan konseling dan pengetahuan agama yang cukup mendalam.

Kesempurnaan panduan konseling Islami berbasis model Gerald Corey ditambah dengan adanya beberapa catatan, masukan, dan saran berupa: a) ayat AI Qur'an sebaiknya disertakan tafsir, b) penggunaan Bahasa Arab disertakan terjemahnya, dan 3) teknik konseling cerita ditambah dengan siroh, dikaitkan dengan suri tauladan, dan dengan cerita para ulama terdahulu, sedangkan catatan dan saran lainnya berupa: a) gambar yang digunakan diberi keterangan, b) teknik-teknik konseling ditambah dengan masalah-masalah yang mungkin bisa ditangani, dan c) 
hadits yang digunakan disertakan arabnya. Berdasarkan catatan yang diberikan oleh kedua uji pengguna tersebut, maka diadakan perbaikan pada panduan yang dikembangkan.

Pelaksanaan konseling Islami tersebut terwujud pada salah satu sekolah Islam yaitu SMP Ar-Rohmah Putri. Program BK bernafaskan Islam di sekolah SMP Ar-Rohmah Putri mulai ada pada tahun 2009 dengan satu guru BK yaitu Ibu Vonny Fatimah, S.Pd sekaligus merangkap kordinator BK. Peranan BK pada sekolah sangatlah penting untuk menunjang keberhasilan pendidikan. Sebagaimana yang dinyatakan oleh Salahudin (2010) bahwa tujuan umum pelayanan BK pada dasarnya sejalan dengan tujuan pendidikan itu sendiri karena BK adalah bagian integral dari sistem pendidikan.

Dengan demikian, panduan konseling Islami berbasis model Gerald Corey memenuhi kriteria sangat tepat/sesuai. Kriteria tersebut menunjukkan panduan konseling Islami berbasis model Gerald Corey sudah memenuhi aspek sangat sesuai materi dan sangat praktis pelaksanaan konseling Islami dengan konseling model Gerald Corey. Hal ini juga disesuaikan dengan konsep kriteria dan penilaian dalam buku Standars for Evaluatonal Program, Project and Materials yang dikembangkan oleh The Joint Committe on Standars for Educational Evaluations (1981).

Setelah dilakukan penelitian, pengembangan, koreksi, revisi, validasi, dan revisi lagi. Jika revisi dengan masukan terakhir dari uji ahli BK, BKI, media pembelajaran, dan pengguna sudah dilakukan, maka tuntaslah produk panduan konseling Islami berbasis model Gerald Corey. Produk berupa panduan konseling Islami bisa digunakan untuk masyarakat.

Penelitian ini berimplikasi secara teoritis pada pengembangan ilmu konseling terutama konseling Islami. Penelitian ini menunjukkan bahwa nilai-nilai keagamaan bisa diintegrasikan dalam ilmu konseling dan bisa bermanfaat serta berterima baik bagi konselor maupun konseli. Secara praktis, temuan penelitian ini bisa menjadi alternatif bagi sekolah dengan basis Islam, seperti madrasah, untuk menggunakan panduan dan teknik-teknik konseling yang sesuai dengan keyakinan konseli. Banyaknya sekolah Islam di Indonesia, baik Madrasah Ibtidayah (MI), Madrasah Tsanawiyah (MTs), Madrasah Aliyah (MA), maupun sekolah pesantren keberadaan BK dengan nuansa Islami pada sekolah tersebut menjadi penting. Perguruan Tinggi Agama Islam (PTAI) pencetak konselor Islam juga bisa menjadikan panduan ini sebagai rujukan dalam mata kuliah bimbingan dan konseling Islam.

Namun, penelitian ini tentu saja memiliki keterbatasan. Panduan yang dikembangkan masih berupa prototype yang memerlukan pengujian yang lebih luas. Pengguna dalam penelitian ini masih terbatas pada dua orang konselor di lembaga pendidikan tingkat menengah pertama. Oleh sebab itu, penelitian lanjutan diperlukan dengan melibatkan pengguna yang lebih bervariasi baik dari segi gender, tingkat lembaga pendidikan, geografis, maupun latar sosial budaya yang berbeda dengan penelitian sekarang. Penelitian dengan latar belakang pengguna yang lebih bervariasi tentu akan memberikan data yang lebih komprehensif untuk menjadi masukan maupun kritik pengembangan panduan konseling Islami di masa depan.

Penelitian ini hanya melaksanakan revisi produk akhir dengan penguji ahli dan uji calon pengguna, belum pada tahap implementasi. Karena itu, diperlukan tindak lanjut. Penelitian dapat dilanjutkan dengan mendeseminasi dan mengimplementasi di lapangan. Saran pemanfaatan yang dapat dikemukakan, yaitu; 1) konselor perlu memiliki kompetensi, wawasan dan pemahaman Islam yang mendalam. 2) konselor perlu mempertimbangkan konseli akan kebutuhan atau kebersediannya konseling dengan pendekatan konseling Islami. Diseminasi dan pengembangan produk lebih lanjut juga bisa dilakukan dengan menambah jumlah ahli untuk validasi produk. Peneliti lebih lanjut, dapat menguji pengalaman pengguna melalui kegiatan penelitian eksperimen, sehingga efektivitas produk dapat diukur secara empiris. 


\section{Simpulan}

Panduan konseling Islami berbasis model Gerald Corey dinilai tepat/sesuai karena secara sistematis telah memuat: 1) hakikat manusia menurut Islam, 2) perkembangan perilaku dalam Islam meliputi struktur kepribadian Islam dan pribadi sehat dan yang tidak sehat dalam Islam, 3) hakikat konseling Islami, 4) kondisi pengubahan meliputi tujuan konseling Islami, sikap dan tugas konselor Islam, dan sikap, peran dan tugas konseli, serta situasi hubungan konseling Islami, 5) mekanisme pengubahan mencakup tahap-tahap konseling Islami dan teknik-teknik konseling Islami yang telah sistematis dalam konseling. Panduan konseling Islami telah memenuhi kriteria tepat/sesuai karena sesuai dengan konsep konseling Islami. Hasil penelitian juga menunjukkan panduan konseling Islami dapat dikembangkan. Konsep konseling Islami perlu dibahas baik dalam seminar, diskusi maupun kegiatan keilmiahan lain, sehingga memberikan konsep yang utuh.

\section{Ucapan Terima Kasih}

Ucapan terima kasih kepada Prof. Dr. Fattah Hanurawan, M.Si., M.Ed. dan Prof. Dr. Blasius Boli Lasan, M.Pd atas masukannya dalam penyelesaian penelitian dan tulisan ini. Terima kasih juga kepada para partisipan penelitian yang telah sukarela membantu dalam proses pengumpulan data.

\section{Daftar Rujukan}

A.Said Hasan Basri, Zaen Musyrifin, M. K. A. dan H. K. R. (2019) 'Pengembangan Model Keilmuan Bimbingan Dan Konseling Islam Melalui Jurnal Hisbah: Jurnal Bimbingan Konseling Dan Dakwah Islam', Jurnal Al Isyraq, 2(2), pp. 136-158.

Akbari, M. and Hossaini, S. M. (2018) 'The relationship of spiritual health with quality of life, mental health, and burnout: The mediating role of emotional regulation', Iranian journal of psychiatry, 13(1), p. 22.

Amin, S. M. (2010) Bimbingan dan Konseling Islam. Jakarta: Amzah.

Ardani, T. A., Yusuf, A. Y. and Irawan, A. R. (2020) 'PSIKORELIGIUSITAS DALAM PENINGKATAN KESEHATAN MENTAL CALON JAMAAH HAJI DAN UMROH DI KOTA MALANG', in Seminar Nasional Psikologi UM.

Ardi, A. (2019) 'Peran Bimbingan Konseling Islam Mengatasi Kecanduan Game Online', Ekspose: Jurnal Penelitian Hukum dan Pendidikan, 18(1), pp. 802-810. doi: 10.30863/ekspose.v18i1.370.

Arifin, I. Z. (2013) 'MODEL BIMBINGAN DAN KONSELING ISLAMI UNTUK MEMENUHI KEBUTUHAN SPIRITUAL PASIEN RAWAT INAP DI RUMAH SAKIT: Studi ke Arah Pengembangan Model Bimbingan dan Konseling Islami di Rumah Sakit Umum Daerah Al-Ihsan Kabupaten Bandung'. Universitas Pendidikan Indonesia.

Arifin, S. and Munfaridah, H. (2018) 'Pengembangan Desain Konseling Berbasis Pesantren dengan Pendekatan Service-Learning', Jurnal Bimbingan dan Konseling Islam, 8(2), pp. 110-132.

Ashshidieqy, H. (2018) 'Hubungan kecerdasan spiritual terhadap prestasi belajar siswa', JPPPJurnal Penelitian dan Pengukuran Psikologi, 7(2), pp. 68-75.

Atmoko, A. (2009) 'Konseling Religius: Kerangka Kerja untuk Bimbingan Skripsi', in Seminar Internasional dalam rangka Kongres XI dan Konvensi Nasional XVI Asosiasi Bimbingan dan Konseling Indonesia (ABKIN). Surabaya.

Bastomi, H. (2017) 'Menuju Bimbingan Konseling Islami', KONSELING EDUKASI" Journal of Guidance and Counseling", 1(1).

Bogdan, R. C. and Biklen, S. K. (2003) Qualitative Research for Education: An. Introduction to Theory and Methods. Boston: Allyn and Bacon.

Brophy, M. (2015) 'Spirituality incorporated: Including convergent spiritual values in business', 
Journal of business ethics, 132(4), pp. 779-794.

Corey, G. (2017) Theory and practice of counseling and psychotherapy. Nelson Education.

Darmadi, H. (2011) Metode Penelitian Pendidikan. Bandung: Alfabeta.

Daulay, M. (2018) 'Urgensi Bimbingan Konseling Islam Dalam Membentuk Mental Yang Sehat', Hikmah, 12(1), p. 145. doi: 10.24952/hik.v12i1.859.

Diniaty, A. (2013) 'Urgensi Teori Konseling Dan Perspektifnya Dalam Islam Menjawab Tuntutan Konseling Religius Di Masa Depan', Al-Ta lim Journal, 20(1), pp. 312-232. doi: 10.15548/jt.v20i1.27.

Edison, E. (2018) 'PENGEMBANGAN MODEL KONSELING ISLAMI UNTUK MENINGKATKAN KEDISIPLINAN SISWA DI SMA NEGERI 8 MAKASSAR'. UNIVERSITAS NEGERI MAKASSAR.

Edison, E. (2020) 'Development of Islamic Counseling Models To Improve Student's Discipline', Jurnal Psikologi Pendidikan dan Konseling: Jurnal Kajian Psikologi Pendidikan dan Bimbingan Konseling, 6(1), pp. 57-65.

Ellison, C. G. et al. (2013) 'Spiritual struggles and mental health: Exploring the moderating effects of religious identity', International Journal for the Psychology of Religion, 23(3), pp. 214229.

Fadhilah, N. (2017) 'Pengembangan Model Bimbingan Kelompok Berbasis Islami untuk Meningkatkan Kecerdasan Emosional Siswa', Jurnal penelitian, pp. 111-130.

FERNANDY, N. (no date) 'Hubungan Spiritualitas dengan Stres Pengasuhan Ibu yang Memiliki Anak Retardasi Mental'.

Fitri, A. (2018) 'Pendidikan karakter prespektif al-Quran hadits', TA'LIM: Jurnal Studi Pendidikan Islam, 1(2), pp. 258-287.

Gall, M. D., Gall, J. P. and Borg, W. R. (2007) Educational research : an introduction. Boston: Pearson.

Gonçalves, J. P. B. et al. (2015) 'Religious and spiritual interventions in mental health care: a systematic review and meta-analysis of randomized controlled clinical trials', Psychological medicine, 45(14), pp. 2937-2949.

Gudnanto, G. (2015) 'Peran Bimbingan Dan Konseling Islami Untuk Mencetak Generasi Emas Indonesia', Jurnal Konseling Gusjigang, 1(1), p. 106908.

Gustini, N. (2016) 'Bimbingan Dan Konseling Melalui Pengembangan Akhlak Mulia Siswa Berbasis Pemikiran Al-Ghazali', Tadris: Jurnal Keguruan dan IImu Tarbiyah, 1(1), pp. 114.

Hallen (2005) Bimbingan dan Konseling. Jakarta: Quantum Teaching.

Hayat, A. (2011) 'Pengembangan konsep konseling islami (konsep konseling berdasarkan ayatayat Al-Qur'an)', Ta'lim Muta'allim, 1(2), p. Juli-Desember.

Hayat, A. (2016) Konsep Konseling Berdasarkan Ayat-Ayat Al-Qur'an (Jilid I). 1st edn. Yogyakarta: LKiS Pelangi Aksara.

Hayat, A. (2017) Bimbingan Konseling Qur'ani (Jilid 1). LKIS PELANGI AKSARA.

Hyland, T. (2017) 'McDonaldizing spirituality: Mindfulness, education, and consumerism', Journal of Transformative Education, 15(4), pp. 334-356.

INDRA, I. (2020) 'KONSELING SPIRITUAL PADA PENDERITA GANGGUAN MENTAL DIPONDOK PESANTREN REHABILITAS SALAFIYAH SYAFI'IYAH NASRUN MINALLAH YOGYAKARTA', MEDIA INTELEKTUAL MUSLIM DAN BIMBINGAN ROHANI, 6(1).

Indrayati, S. A. (2020) 'Efektifitas Layanan Bimbingan dan Konseling Islam dalam Meningkatkan Kualitas Pribadi Siswa di SMA Negeri 7 Yogyakarta', G-Couns: Jurnal Bimbingan dan Konseling, 5(1), pp. 23-30.

Lestari, I. (2014) 'Pengembangan Media Bimbingan Dan Konseling Berbasis Islami Untuk Membentuk Karakter Mandiri Anak Usia Dini', Refleksi Edukatika: Jurnal IImiah Kependidikan, 4(1).

Lubis, S. A. (2011) 'Islamic counseling: The services of mental health and education for people', Religious Education, 106(5), pp. 494-503.

Ma'ruf, H. (2014) Landasan Bimbingan dan Konseling Perspektif Islam dan Filsafat EksistensialHumanistik: Sebuah Komparasi. Yogyakarta: Aswaja. 
Martinez, B. B. and Custodio, R. P. (2014) 'Relationship between mental health and spiritual wellbeing among hemodialysis patients: a correlation study', Sao Paulo medical journal, 132(1), pp. 23-27.

Maulana, R. (2016) 'Pengembangan model bimbingan kelompok berbasis islami untuk meningkatkan kecerdasan sosial siswa SMK', Jurnal Psikologi Pendidikan dan Konseling: Jurnal Kajian Psikologi Pendidikan dan Bimbingan Konseling, 2(1), pp. 58-65.

McGhee, P. and Grant, P. (2017) 'The transcendent influence of spirituality on ethical action in organizations', Journal of management, spirituality \& religion, 14(2), pp. 160-178.

Moleong, L. J. (2011) Metode Penelitian Kualitatif. Bandung: Remaja Rosdakarya.

Østbø, J. (2017) 'Securitizing "spiritual-moral values" in Russia', Post-Soviet Affairs, 33(3), pp. 200-216.

Pearce, M. J. et al. (2019) 'A novel training program for mental health providers in religious and spiritual competencies.', Spirituality in Clinical Practice, 6(2), p. 73.

Ristianti, D. H. (2018) 'Konseling Islami Untuk Meningkatkan Efikasi Diri Pasien HIVIAIDS', Indonesian Journal of Educational Counseling, 2(1), pp. 113-130.

Rozikan, M. (2017) 'Transformasi dakwah melalui konseling islami', INJECT (Interdisciplinary Journal of Communication), 2(1), pp. 77-98.

Rudyanto, E. (2010) 'Hubungan antara kecerdasan emosi dan kecerdasan spiritual dengan Perilaku Prososial pada Perawat'.

Sabiq, Z. (2012) 'Kecerderdasan emosi, kecerdasan spiritual dan perilaku prososial santri pondok pesantren nasyrul ulum pamekasan', Persona: Jurnal Psikologi Indonesia, 1(2).

Salahudin, A. (2010) Bimbingan dan Konseling. Bandung: Pustaka Setia.

Satriah, L., Tajiri, H. and Yuliani, Y. (2019) 'Konseling Islami untuk Pengembangan Parenting Skills Orang Tua', Konvensi Nasional Bimbingan dan Konseling XXI, pp. 60-67.

Siregar, R. (2015) 'Pengembangan fitrah manusia melalui konseling Islam', FITRAH: Jurnal Kajian IImu-ilmu Keislaman, 1(1), pp. 1-14.

Siswanti, Y., Muhsin, A. and Nafisah, L. (2020) 'Analisis Kepemimpinan Spiritual, Perilaku Kerja Spiritual, dan Kesadaran Lingkungan Terhadap Environmental Passion', Eksos LPPM, 2(1), pp. 78-85.

Solihin, M. and Rosihon, A. (2004) Hakikat Manusia Menggali Potensi Kesadaran Pendidikan Dini dalam Psikologi Islam. Bandung: Pustaka Setia.

Stepanova, E. (2015) "The Spiritual and Moral Foundation of Civilization in Every Nation for Thousands of Years": The Traditional Values Discourse in Russia', Politics, Religion \& Ideology, 16(2-3), pp. 119-136.

Sukmadinata, N. S. (2012) Metode Penelitian Pendidikan. Bandung: Remaja Rosdakarya.

Sutoyo, A. (2017) 'Model Bimbingan Dan Konseling Sufistik Untuk Mengembangkan Pribadi Yang 'Alim Dan Saleh', Konseling Religi : Jurnal Bimbingan Konseling Islam, 8(1), pp. 1-22.

Tambunan, S. (2018) 'Seni Islam Terapi Murattal Alquran Sebagai Pendekatan Konseling Untuk Mengatasi Kecemasan', Al-Mishbah: Jurnal Ilmu Dakwah dan Komunikasi, 14(1), pp. 7589.

The Joint Committee on Standards For Educational Evaluation (1981) Standards for Evaluations of Educational Program, Projects, and Materials. New York.

Trianto (2011) Pengantar Penelitian Pendidikan bagi Pengembangan dan Profesi

Pendidikan Tenaga Kependidikan. Jakarta: Prenada Media Group.

TYAS, J. M. (no date) 'Hubungan Tingkat Kemandirian Akivitas Sehari-hari dengan

Tingkat Spiritualitas Lansia di UPT PSTW Jember'.

UM, W. D. P. (2020) 'Pengembangan panduan konseling islami berdasarkan model

Gerald Corey/Ermalianti', SKRIPSI Mahasiswa UM.

Unterrainer, H.-F., Lewis, A. J. and Fink, A. (2014) 'Religious/spiritual well-being, personality and mental health: a review of results and conceptual issues', Journal of religion and health, 53(2), pp. 382-392.

Ushatikova, I. I. et al. (2018) 'Christian values in spiritual and moral upbringing of students', European Journal of Science and Theology ISSN, 1841-0464, 14(5), p. 77.

Vafaee, R. (2015) 'Association of between mental health and spiritual health among students in Shiraz University', Advances in Nursing \& Midwifery, 24(84), pp. 53-59. 
Vitell, S. J. et al. (2016) 'Spirituality, moral identity, and consumer ethics: A multi-cultural study', Journal of business ethics, 139(1), pp. 147-160.

Zakaria, N. and Akhir, N. S. M. (2017) 'Theories and modules applied in Islamic counseling practices in Malaysia', Journal of religion and health, 56(2), pp. 507-520.

\section{Competing interests:}

The authors declare that they have no significant competing financial, professional or personal interests that might have influenced the performance or presentation of the work described in this manuscript. 